\title{
An uncommon cause of acute abdomen: gastric duplication cyst
}

\section{Akut batının nadir bir sebebi: gastrik duplikasyon kisti}

\author{
Gökhan Demiral ${ }^{1}$, Berat Dilek Demirel ${ }^{2}$ \\ ${ }^{1}$ Sağlık Bakanlığı Recep Tayyip Erdoğan Üniversitesi Eğitim Ve Araştırma Hastanesi, Rize \\ ${ }^{2}$ Kadın Hastalıkları ve Doğum Hastanesi, Samsun
}

Dergiye Ulaşma Tarihi: 10.10.2017 Dergiye Kabul Tarihi:23.11.2017 Doi: 10.5505/aot.2018.82621

\section{ÖZET}

Gastrik duplikasyon kistleri gastrointestinal sistemin nadir konjenital anomalilerindendir. Hastaların çoğu kusma, iştahsızlık ve beslenme bozukluğu ile başvurur. Olguların yarısı ilk yaş içerisinde tanı alır. Bu çalışmada akut batın sebebi ile başvuran ve gastrik duplikasyon kisti saptadığımız on yaşında ki bir olgu sunulmuştur. Çocuklarda nadir görülen gastrik duplikasyon kistlerinin akut batın nedeni olarak karşımıza çıkabileceği akılda tutulmalıdır.

Anahtar Kelimeler: Gastrik duplikasyon kisti, akut batın, ayırıcı tanı

\begin{abstract}
Gastric duplication cyst is a rare congenital anomaly of the gastrointestinal system. Patients are mostly presented with vomiting, anorexia and malnutrition. Half of the cases are diagnosed in the first year of life. In this study, we report a 10 year old girl with gastric duplication cyst that was presented as acute abdomen.

Keywords: Gastric duplication cyst, acute abdomen, differential diagnosis
\end{abstract}

\section{INTRODUCTION}

Gastric duplication cyst (GDC) is a congenital anomaly of the gastrointestinal tract. Some clinical findings emerge according to the location of the cyst. Patients mostly present with vomiting, anorexia and malnutrition. Half of the cases are diagnosed in the first year of life (1). It may very rarely reported in adults if it remains asymptomatic on previous years (2). GDC may be presented with inracystic bleeding, ulceration, infection, mechanical obstruction and malignancy $(3,4)$. In this study we present a ten years old girl who was operated as acute abdomen and pathologically reported as GDC.

\section{CASE REPORT}

Ten-year-old cachectic girl $(23 \mathrm{~kg} ; 3-10 \%$ percentiles) was admitted to the emergency department with vomiting and abdominal pain increasing in severity for the last three days. It was learned from anamnesis that she was unable to gain weight since infancy. Diffuse abdominal tenderness, defense and rebound were observed on physical examination. On routine laboratory tests high leukocyte count [14,56 (4,5-12 $\mu \mathrm{L})]$ and high CRP [12,1 (0-0,5 mg/Dl)] levels were observed. Other parameters were within normal limit. On radiological evaluation with abdominal ultrasonography (USG) and computurised tomography (CT) a $7 \mathrm{~cm}$ in diameter thick-walled mass lesion was defined in the medial neighborhood of the liver (Figure 1). Patient was decided to underwent surgery for acute abdomen and informed consent was taken from parents. Laparotomy was performed through upper midline incision. At laparatomy a $7 \times 5 \times 5 \mathrm{~cm}$ in diameter infected, partially necrotised and purulent material containing solid mass lesion was detected in gastric antum with indistinct boundaries (Figure 2,3). The mass lesion and adjacent partial gastric mucosa was resected with clear surgical margins (Figure 4). The nasogastric drainage tube was withdrawn and oral feeding with liquids was allowed on 3rd postoperative day. She was discharged without any problem on the sixth day. Histopathological examination was reported as gastric duplication cyst with heterotopic pancreas tissue around the mass (Figure 5). Six months later on control examination the patient was observed as weight 
gained ( $28 \mathrm{~kg} ; 10-25 \%$ percentiles) and without any complaint.

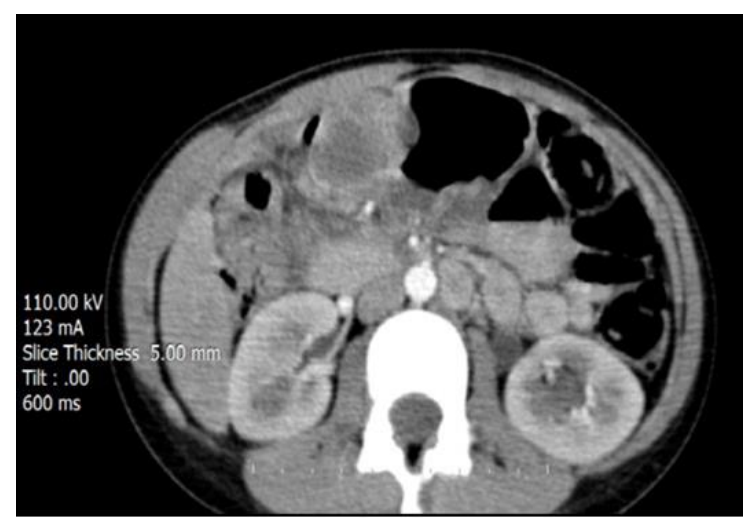

Figure 1: GDC is located on medial neighborhood of the liver on abdominal computurised tomography (GDC: Gastric duplication cyst).

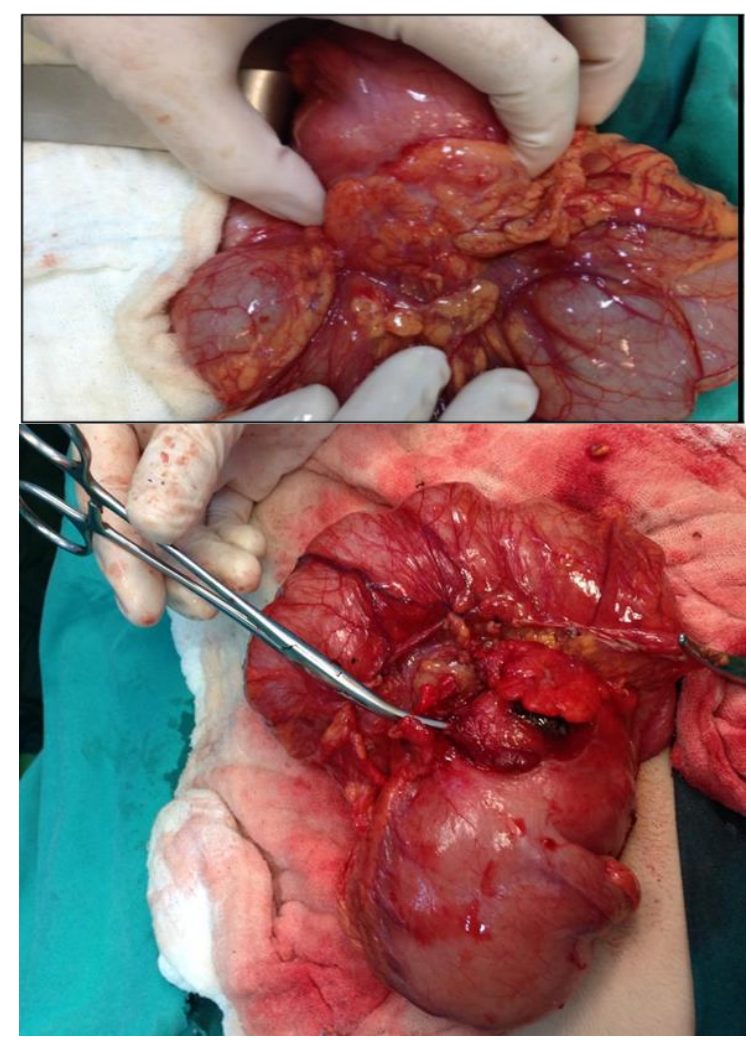

Figure 2-3: GDC as an infected, partially necrotised and purulent material containing solid mass on antrum of stomach

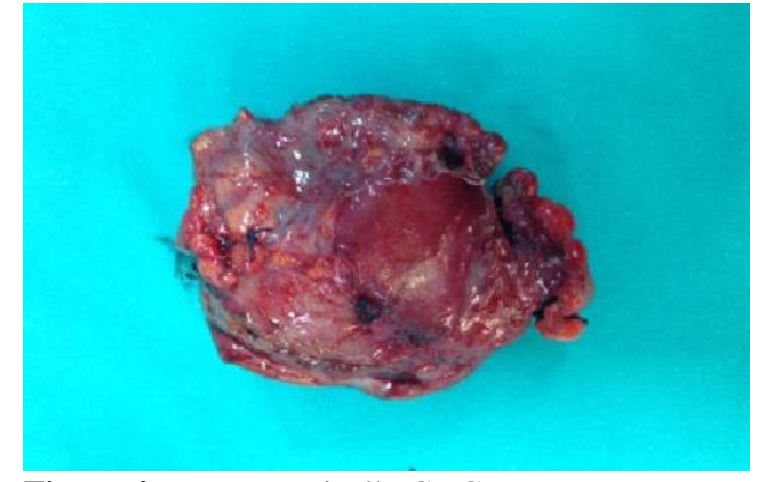

Figure 4: Macroscopically GDC

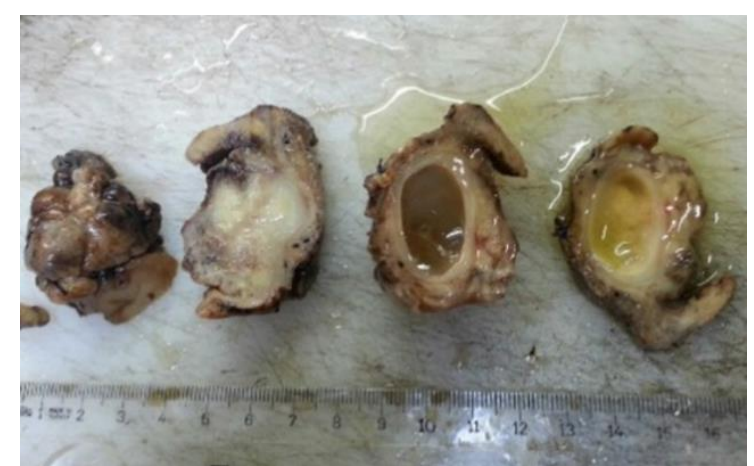

Figure 5: Pathological cross sectional appearances of GDC.

\section{DISCUSSION}

Gastrointestinal duplication cysts are rare congenital anomalies and usually affect small intestine $(45 \%)$ and esophagus $(19 \%)(5,6)$. Its frequency in autopsy studies is $1 / 4500$ (7). The incidence of GDC among all gastrointestinal duplications is $4 \%(6,8)$. It is commonly located on greater curvature (9) as it was in our case. The patients are mostly diagnosed in the first few years of life with abdominal pain, vomiting, weight loss and palpable abdominal mass or other gastrointestinal obstruction signs $(1,8,10)$. Adult patients are usually asymptomatic or admitted with nonspecific symptoms (11). The clinical presentation depends on the location of the mass (1). The disease may mimic hypertrophic pyloric stenosis in adults. Also the patients may be hospitalised due to acute bleeding of the cyst or with pancreatitis $(4,10,12)$. In a 83 patients study, Pruksapong et al. reported a palpable abdominal mass in 55 patients $(66.2 \%)$ and vomiting in 53 patients (63.8\%) (13). Our case was admitted with abdominal pain, vomiting and cachexia. On physical examination it was also compatible with acute abdomen. There were only a few 
cases in the literature review presented with acute abdomen.

In some adults; GDC may be detected incidentally during upper gastrointestinal system endoscopy, endoscopic USG or other intraabdominal investigation processes $(9,14,15)$. Due to the limited number of cases it has not yet become obvious what kind of evidences can help us to detect the disease in early stage. Most of the cases can not be diagnosed preoperatively (7). Our case was also considered as delayed gastric perforation or intraabdominal mass preoperatively.

In differential diagnosis gastric tumors, pancreatic mucinous and cystic tumors, pancreatic psodocysts, cystic masses of adjacent organs, gastrointestinal stromal tumors and neuroendocrine tumors should be considered $(5,8)$. GDCs are sometimes diagnosed incorrectly as adrenal masses due to the anatomical proximity of the adrenal glands $(5,11)$.

CT is helpful in determining the size of the cyst and the relationship with the neighboring organs (5). CT indicates the GDC as in oval or round shaped, smooth bordered, water or soft tissue density, homogeneous and low density lesion. The contrast agent and calcifications can be seen on cystic wall (2). The mass lesion was described as thick walled on abdominal CT in our case. Endoscopic USG and magnetic resonance imaging (MRI) may be performed on undiagnosed cases in case of difficulty in diagnosis. Hyperintense pattern is expected on T1 and T2 weighted MRI examination depending on rich protein content (2). CT-guided needle biopsy may be preferred preoperatively in some cases although its sensititity is not satisfactory

Histopathological examination is still the most basic process for definitive diagnosis of the GDC (8).

The treatment of GDC is the surgical excision. Simple cyst excision, gastroduodenostomy with cyst excision and pyloroantrectomy may be performed either conventionally or laparoscopically $(7,11,16)$. Although the actual potential of malignity has not been discovered it has been postulated in some reports that GDC may result in gastric cancer (17) and total excision of the cyst tends to be the standard approach (11). Marsupialization, CT-guided cyst drainage or partial excision methods may allow the improvement of symptoms. However these methods should be avoided due to the infection potential, recurrence of the cyst and risk of the malignancy $(7,11)$.

\section{CONCLUSION}

GDC is quite rarely seen in childhood and should always be kept in mind in the differential diagnosis of the masses of the gastric wall. It may result in weight loss and can present as a reason of acute abdomen. Total surgical excision should be preffered treatment modality.

Conflict of Interest: There is no conflict of interest.

\section{REFERENCES}

1. Gupta S, Sleeman D, Alsumait B, Abrams L. Duplication cyst of the antrum: a case report. Can J Surg 1998; 413: 248-50.

2. Macpherson RI. Gastrointestinal tract duplications: clinical, pathologic, etiologic, and considerations. Radiographics 1993; 13: 1063-80.

3. Menon P, Rao KL, Saxena AK. Duplication cyst of the stomach presenting as hemoptysis. Eur J Pediatr Surg 2004; 14: 429-31.

4. Stephen TC, Bendon RW, Nagaraj HS, Sachdeva R. Antral duplication cyst: a cause of hypergastrinemia, recurrent peptic ulceration, and hemorrhage. J Pediatr Gastroenterol Nutr 1998; 26: 216-8.

5. Liu K, Lin $X$, Wu J, Liu H, Meng M, Su H, et al.Peritoneal metastatic adenocarcinoma possibly d ue to a gastric duplication cyst: a case report and literature review. BMC Gastroenterol 2014; 14: 48.

6. Agha FP, Gabriele OF, Abdulla FH. Complete gastric duplication. AJR 1981; 137: 406-7.

7. Sharma D, Bharany RP, Mapshekhar RV.Duplication cyst of pyloric canal:a rare cause of pediatric gastricoutletobstruction: rare case report. Indian J Surg 2013; 75: 322-5.

8. Deesomsak $\mathrm{M}$, Aswakul $\mathrm{P}$, Junyangdikul $\mathrm{P}$, Prachayakul V. Rare adult gastric duplication cyst mimicking a gastrointestinal stromal tumor. World J Gastroenterol 2013; 7: 8445-8.

9. Zheng $J$, Jing $H$. Adenocarcinoma arising from a gastric duplication cyst. Surg Oncol 2012; 21: 97 101

10. Hlouschek V, Domagk D, Naehrig J, Siewert JR, Domschke W. Gastric duplication cyst: a rare endosonographic finding in an adult. Scand $\mathbf{J}$ Gastroenterol 2005; 40: 1129-31.

11. .Belli S, Noyan T, Kayaselçuk F, Erbay G. Gastric duplication (bronchogenic) cyst mimicking a gastrointestinal stromal tumour. Ulusal Cer Derg 2013; 29: 35-7. 
12. Katz W, Annessa G, Read RC. Gastric duplication with pancreatic communication. Presenting as pancreatitis. Minn Med 1967: 50: 1175-9.

13. Pruksapong C, Donovan RJ, Pinit A, Heldrich FJ. Gastric duplication. J Pediatr Surg 1979; 14: 83-5.

14. Takahara $T$, Torigoe $T$, Haga $H$, Yoshida $H$, Takeshima S, Sano S, et al. Gastric duplication cyst: evaluation by endoscopic ultrasonography and magnetic resonance imaging. J Gastroenterol 1996; 31: 420-4.

15. Napolitano V, Pezzullo AM, Zeppa P, Schettino $\mathrm{P}$, Armiento MD, Palazzo A, et al. Foregut duplication of the stomach diagnosed by endoscopic ultrasound guided fine-needle aspiration cytology: case report and literature review. World J Surg Oncol 2013; 11: 33.

16. Wakabayashi H, Okano K, Yamamoto N, Suzuki Y, Inoue $\mathrm{H}$, Kadota $\mathrm{K}$, et al. Laparoscopically resected foregut duplication cyst (bronchogenic) of the stomach. Dig Dis Sci 2007; 52: 1767-70.

17. Kuraoka K, Nakayama H, Kagawa T, Ichikawa T, Yasui W. Adenocarcinoma arising from a gastric duplication cyst with invasion to the stomach: a case report with literature review. J Clin Pathol 2004; 57: 428-31. 